Jurnal Riset Agama

Volume 1, Nomor 3 (Desember 2021): 157-170

DOI: $10.15575 /$ jra.v1i3.15125

https://journal.uinsgd.ac.id/index.php/jra

\title{
Nilai-nilai Inti Sistem Manajemen Strategis pada Pengelolaan Pendidikan Tinggi: Studi Living Hadis
}

\author{
Siti Rahmah"1, Wahyudin Darmalaksana², Susanti Vera ${ }^{3}$, Muhamad Yoga \\ Firdaus $^{4}$, Hidayatul Fikra ${ }^{5}$ \\ 1,2Program Studi Ilmu Hadis, Fakultas Ushuluddin \\ UIN Sunan Gunung Djati Bandung, Indonesia \\ 3,4Jurusan Ilmu Al-Qur'an dan Tafsir, Program Pascasarjana \\ UIN Sunan Gunung Djati Bandung, Indonesia \\ 5Jurusan Tasawuf Psikoterapi, Fakultas Ushuluddin \\ UIN Sunan Gunung Djati Bandung, Indonesia \\ strhmaah@gmail.com, yudi_darma@uinsgd.ac.id, \\ yogafirdaus@uinsgd.ac.id, susantivera96@gmail.com, \\ fikraarza2903@gmail.com
}

\begin{abstract}
This study aims to discuss the core values in strategic management systems. This research method is qualitative through literature study with a living hadith approach which is a case study in Islamic higher education. The results and discussion of this research are in the form of a vision, mission, goals, strategic objectives, and core values of Islamic higher education institutions. These are substantially understood as a manifestation of the management of the Prophet, as a noble person with al-Qur'an morals. This study concludes that the relevant living hadith approach is used for research on the core values of strategic management systems that are initiated by institutions in their efforts to achieve strategic goals. The recommendation of this research is the importance of developing hadith studies and developing value-based institutions as a reference for decision making.
\end{abstract}

Keyword: Living Hadith; Strategic Goals; Strategic Management; Strategic Plans.

\begin{abstract}
Abstrak
Penelitian ini bertujuan membahas nilai-nilai inti dalam sistem manajemen strategis. Metode penelitian ini bersifat kualitatif melalui studi pustaka dengan pendekatan living hadis yang merupakan studi kasus di pendidikan tinggi Islam. Hasil dan pembahasan penelitian ini berupa visi, misi, tujuan, sasaran strategis, dan nilai-nilai inti lembaga pendidikan tinggi Islam,
\end{abstract}


Jurnal Riset Agama, Volume 1, Nomor 3 (Desember 2021): 157-170

Siti Rahmah, Wahyudin Darmalaksana, Susanti Vera, Muhamad Yoga Firdaus, Hidayatul Fikra/Nilai-nilai Inti Sistem Manajemen Strategis pada Pengelolaan Pendidikan Tinggi: Studi Living Hadis

hal ini secara substansial dipahami sebagai manifestasi manajemen dari Nabi Saw., sebagai pribadi mulia dengan ahlak al-Qur'an. Penelitian ini menyimpulkan bahwa pendekatan metode living hadis relevan digunakan untuk penelitian nilainilai inti sistem manajemen strategis yang menjadi inisiatif lembaga dalam upaya mereka melakukan pencapaian sasaran strategis. Rekomendasi penelitian ini adalah pentingnya pengembangan studi hadis dan pengembangan lembaga berbasis nilai sebagai rujukan pengambilan keputusan.

Kata Kunci: Living Hadis; Manajemen Strategis; Rencana Strategis; Sasaran Strategis.

\section{Pendahuluan}

Living hadis sebagai sebuah metode penelitian hadis beroperasi pada bidang-bidang yang luas, termasuk metode ini mampu mengungkap dimensi manajemen lembaga Islam. Mengoperasikan metode living hadis untuk mengungkap dimensi manajemen lembaga merupakan subjek baru. Suatu lembaga pasti menerapkan nilai-nilai inti (core values) pada sistem manajamen strategis (Yu \& Sangiorgi, 2018). Terlebih pada lembaga Islam, nilai-nilai inti yang diterapkan dalam sistem manajamen strategis (strategic manajement system) dipastikan dilandaskan pada nilai-nilai dasar Islam, baik dari al-Qur'an maupun dari hadis (Darmalaksana et al., 2017). Dalam hal ini, metode living hadis berperan untuk meneliti nilai-nilai hadis (Qudsy, 2016) yang diterapkan pada sistem manajamen strategis suatu lembaga. Penelitian ini berfokus untuk mengoperasikan metode living hadis dalam membahas nilai-nilai inti hadis pada sistem manajamen strategis lembaga.

Metode living hadis bukan subjek yang asing sekarang ini. Arti living berasal dari Bahasa Inggris yaitu "hidup." Dikaitkan dengan hadis berarti living hadis ialah "hadis yang hidup"(Anwar, 2015). Hadis sama artinya dengan sunnah Nabi Saw. (Soetari, 1994), sehingga dikenal pula istilah living sunnah (Salleh et al., 2020). Living hadis (living sunnah) merupakan sebuah metode untuk penelitian hadis atau sunnah (Qudsy, 2016). Penelitian hadis melalui operasi metode living hadis dapat mencakup penelitian tradisi (Rohmana, 2015), sosial-budaya (Dewi, 2017), (Assagaf, 2015), dan kebiasaan (Muhsin, 2015). Sejalan dengan berkembangnya berbagai model living hadis (Suryadilaga, 2005), maka metode living Hadis dipahami bukan hanya sebatas metodologi (Syamsuddin, 2007), melainkan sebuah epistemologi (Muhammad, 2018). Sehingga living hadis disebut sebagai kerangka dasar keilmuan (Suryadilaga, 2006). Meskipun ada pula yang kurang sepakat dengan operasi living hadis (Salleh et al., 2019). Namun, living hadis dipandang efektif dalam penerapan integrasi- 
Jurnal Riset Agama, Volume 1, Nomor 3 (Desember 2021): 157-170

Siti Rahmah, Wahyudin Darmalaksana, Susanti Vera, Muhamad Yoga Firdaus, Hidayatul Fikra/Nilai-nilai Inti Sistem Manajemen Strategis pada Pengelolaan Pendidikan Tinggi: Studi Living Hadis

interkoneksi keilmuan Islam (Suryadilaga, 2007). Metode living hadis dioperasikan dalam berbagai jenis penelitian, baik kualitatif maupun kuantitatif, dan metode ini juga digunakan sebagai pendekatan kritis dalam penelitian hadis (Hudaeri, 2016). Metode living hadis mampu beroprasi untuk membahas nilai teks hadis (Zuhri \& Dewi, 2018), termasuk pembahasan nilai-nilai inti hadis dalam pelaksanaan sistem manajemen strategis.

Nilai-nilai inti (core values) berperan signifikan (Kurniawan, 2016) dalam sistem manajemen strategis (strategic manajement system) untuk pengelolaan sasaran strategis yang menjadi target pecapaian bersama dalam suatu lembaga, baik perusahaan (Wisdaningrum, 2013) maupun lembaga pendidikan (Sulastri, 2013). Perencanaan strategis (strategic planning) selalu mengawali kiprah pengelolaan suatu lembaga (institution) untuk penyusunan tujuan bersama pada periode tertentu (Mook, 2019). Tercapainya tujuan bersama yang menjadi sasaran strategis suatu lembaga bergantung pada implementasi perancanaan sistem manajemen strategis (Ansoff et al., 2018). Untuk memastikan tercapainya tujuan bersama yang merupakan sasaran strategis lembaga, biasanya sistem manajemen lembaga menyertakan core values melalui kesepakatan bersama (Breuer \& Lüdeke-Freund, 2017). Kalangan profesional manajemen lembaga mengakui bahwa pencapaian sasaran strategis diperankan sangat besar melalui pelaksanaan nilai-nilai inti (Yu \& Sangiorgi, 2018). Nilai-nilai inti (core values) merupakan suatu aksiologis (Fattah, 2015) pelaksanaan lembaga dalam operasi sistem manajemen strategis. Nilai-nilai inti suatu lembaga digali dari nilai luhur, baik nilai agama (Wahab, 2017) maupun nilai budaya (Peterson \& Barreto, 2018). Para ahli tidak ada yang membenturkan sumber-sumber nilai luhur, pada praksisnya seringkali basis nilai-nilai inti lembaga merupakan asimilasi keterpaduan erat antara nilai-nilai atropologi dan nilai-nilai agama (Klass, 2018). Nilai-nilai inti dalam sistem manajemen strategis dikembangkan untuk memastikan sasaran strategis berjalan sesuai yang diharapkan (Pedron et al., 2016). Pertimbangan nilai-nilai inti pada sistem manajemen strategis suatu lembaga berfungsi sebagai rujukan etis perilaku keorganisasian (Lutz et al., 2016) serta etika pengambilan keputusan (decision marking) bagi segala aspek pengembangan kelembagaan (Schwartz, 2016). Tegaslah bahwa bagi suatu lembaga, nilai-nilai inti pengelolaan lembaga merupakan suatu aksiologis pencapaian sasaran strategis (Zhang \& El-Gohary, 2016).

Lembaga pendidikan tinggi Islam (Adhim \& Hakim, 2019) memastikan penggalian nilai-nilai inti dalam perencanaan strategis dimanisfestasikan dari sumber Islam (Samsuni, 2020), yakni Al-Qur'an (Taufiq, 2004) dan hadis (Darmawan et al., 2006). Nilai-nilai inti dari sumber terdalam Al-Qur'an dan hadis lazim mengalami asimilasi dengan nilai-nilai kearifan lokal yang berfungsi merekatkan identitas bangsa 
Jurnal Riset Agama, Volume 1, Nomor 3 (Desember 2021): 157-170

Siti Rahmah, Wahyudin Darmalaksana, Susanti Vera, Muhamad Yoga Firdaus, Hidayatul Fikra/Nilai-nilai Inti Sistem Manajemen Strategis pada Pengelolaan Pendidikan Tinggi: Studi Living Hadis

(Brata, 2016). Lembaga pendidikan tinggi Islam akan memiliki visi, misi, tujuan strategis, dan nilai-nilai institusi (Hakim, 2020). Pada lembaga Islam ada nilai-nilai Islam yang hidup (living), dirawat, dan dilaksanakan dalam pengelolaan sistem manajemen strategis (Firdaus, 2018), terlebih pada lembaga pendidikan tinggi Islam (Adhim \& Hakim, 2019). Sebagai lembaga sektor publik (Oja, 2016), dengan core business pendidikan, yang nirlaba (Sutomo, 2007), lembaga pendidikan tinggi akan menerapkan manajemen strategis (Yunus, 2016), bahkan ada yang secara terang menegaskan sebagai manajemen berbasis nilai (Adhim \& Hakim, 2019). Pada pendidikan tinggi Islam, pelaksanaan nilai-nilai inti Islam diorientasikan dalam rangka pencapaian sasaran strategis yang menjadi tujuan bersama. Penerapan nilai-nilai inti pada pendidikan tinggi Islam, yang digali dari sumber Islam (Samsuni, 2020), yakni Al-Qur'an (Taufiq, 2004) dan hadis (Darmawan et al., 2006), merupakan subjek yang relevan bila dilakukan penelitian dengan metode living (Suryadilaga, 2005), baik living Qur'an (Putra et al., 2018) maupun living hadis (Qudsy, 2016). Akan tetapi, penelitian ini lebih berfokus menerapkan metode living hadis pada manajemen strategis berbasis nilai-nilai inti spritualitas (Eferin, 2016) dari hadis Nabi (Darmawan et al., 2006).

Berdasarkan paparan di atas, formula penelitian ini meliputi rumusan masalah, pertanyaan penelitian, dan tujuan penelitian (Darmalaksana, 2020a). Rumusan masalah penelitian ini adalah, terdapat living hadis nilainilai inti sistem manajemen strategis pendidikan tinggi Islam. Pertanyaannya ialah, bagaimana living hadis nilai-nilai inti sistem manajemen strategis pendidikan tinggi Islam. Tujuan penelitian ini yaitu, membahas living hadis nilai-nilai inti sistem manajemen strategis pendidikan tinggi Islam. Penelitian ini diharapkan memiliki implikasi manfaat bagi peminat ilmu hadis dalam penerapan metode living hadis pada subjek kontemporer (Masrur, 2012) dan bagi peminat pengelolaan sistem manajemen strategis berbasis nilai Islami (Samsuni, 2020).

\section{Metodologi Penelitian}

Metode penelitian ini bersifat kualitatif (Anggito \& Setiawan, 2018) melalui studi pustaka (Darmalaksana, 2020b) dengan studi kasus (Noor, 2008) pembahasan nilai-nilai inti pada Rencana Strategis Fakultas Ushuluddin Universitas Islam Negeri (UIN) Sunan Gunung Djati Bandung pada Periode 2019-2023 (Penyusun, 2019a). Adapun analisis pembahasan nilai-nilai inti pada sistem manajemen startegis lembaga ini digunakan pendekatan living hadis (Darmalaksana et al., 2019).

\section{Hasil Penelitian dan Pembahasan}

Bagian ini terlebih dahulu memaparkan visi, misi, tujuan, dan sasaran strategis Fakultas Ushuluddin UIN Sunan Gunung Djati Bandung periode 
Jurnal Riset Agama, Volume 1, Nomor 3 (Desember 2021): 157-170

Siti Rahmah, Wahyudin Darmalaksana, Susanti Vera, Muhamad Yoga Firdaus, Hidayatul Fikra/Nilai-nilai Inti Sistem Manajemen Strategis pada Pengelolaan Pendidikan Tinggi: Studi Living Hadis

2019-2023 (Penyusun, 2019a). Visi fakultas ini adalah mewujudkan Fakultas Ushuluddin yang unggul di tingkat nasional dan kompetitif di level regional berbasis Wahyu Memandu Ilmu 2019-2023. Visi ini dijawab oleh misi, yaitu: 1) Menciptakan budaya akademik yang moderat dan terintegrasi berdasarkan nilai-nilai keislaman dan keindonesiaan; 2) Menyelenggarakan tridharma perguruan tinggi yang bermutu dan relevan dengan kebutuhan nasional dan tantangan global berbasis wahyu memandu ilmu; dan 3) Menciptakan lulusan yang berdaya saing secara nasional, regional, dan global, bertakwa serta berakhlak mulia.

Misi di atas dijawab oleh tujuan (Penyusun, 2019a), yakni: 1) Mewujudkan lingkungan dan tata kelola akademik yang berkualitas dan ramah yang menunjang tumbuhnya wawasan Islam moderat dalam bingkai Wahyu Memandu Ilmu; 2) Penguatan kurikulum akademik dan non-akademik berbasis Kerangka Kualifikasi Nasional Indonesia (KKNI) dalam proses pengajaran, penelitian dan pengabdian masyarakat berwawasan Wahyu Memandu Ilmu dalam menjawab kebutuhan nasional dan tantangan global; 3) Menyiapkan peserta didik yang memiliki wawasan keilmuan, keislaman dan akhlak mulia melalui program pendidikan dan pembinaan yang jelas dan terukur sehingga dapat berkontribusi pada kemajuan ilmu pengetahuan dan cara hidup berbangsa; dan 4) Meningkatkan peran fakultas melalui kolaborasi, kerjasama dan kemitraan lintas lembaga profesi, perguruan tinggi, pemerintah dan swasta di tingkat lokal, nasional dan regional sehingga lembaga dan lulusan memiliki daya saing di tingkat nasional dan regional.

Tujuan di atas dijawab oleh sasaran strategis (Penyusun, 2019a), yaitu: 1) Meningkatnya pemerataan akses; 2) Meningkatnya kualitas layanan; 3) Meningkatnya kualitas dan kualifikasi pendidik dan tenaga kependidikan; 4) Meningkatnya kualitas hasil penelitian; 5) Meningkatnya relevansi dan daya saing; dan 6) Meningkatnya tata kelola kelembagaan dan otonomi.

Pada masing-masing sasaran strategis terdapat indikator kinerja utama (key performance indicators). Tiap satuan sasaran kinerja terdapat baseline yang merupakan tonggak pencapaian dari kinerja periode terdahulu. Semua sasaran dirumuskan secara terukur untuk target pencapaian tiap tahun dalam periode 2019-2023. Seluruh indikator kinerja utama didistribusi habis ke setiap unit, yang mencakup program studi, laboratorium, dan tata usaha. Indikator kinerja utama bersifat standar yang merupakan hasil kontrak kinerja dengan pimpinan universitas berbasis pada rencana stratgis UIN Sunan Gunung Djati Bandung (Penyusun, 2019b). Adapun standar indikator kinerja utama universitas dihasilkan dari kontrak kinerja pimpinan dengan Direktorat Jenderal Pendidikan Tinggi Islam (Pendis) berbasis pada rencana strategis Kementerian Agama Republik Indonesia (Penyusun, 2020). 
Jurnal Riset Agama, Volume 1, Nomor 3 (Desember 2021): 157-170

Siti Rahmah, Wahyudin Darmalaksana, Susanti Vera, Muhamad Yoga Firdaus, Hidayatul Fikra/Nilai-nilai Inti Sistem Manajemen Strategis pada Pengelolaan Pendidikan Tinggi: Studi Living Hadis

Wahyu Memandu Ilmu (WMI) sendiri merupakan paradigma yang dikembangkan UIN Sunan Gunung Djati Bandung. Halnya paradigma UIN Sunan Kalijaga Yogyakarta, yaitu integrasi interkoneksi (Suharto, 2018). Kementerian Agama RI memberikan mandat pelaksanaan integrasi ilmu pada pendidikan tinggi Islam (Zainiyati, 2015). Sebagai mandat dari Kementerian Agama RI. dalam integrasi ilmu (Tim Penyusun, 2019), WMI menjadi landasan paradigmatik UIN Sunan Gunung Djati Bandung (Penyusun, 2019b).

Untuk memastikan bahwa visi, misi, tujuan dan sasaran strategis berjalan sesuai dengan harapan, fakultas ini mengembangkan tiga nilai utama yang menjadi rujukan perilaku serta pengambilan keputusan seluruh aspek pengembangan kelembagaan (Penyusun, 2019a). Adapun tiga nilai inti tersebut di bawah ini:

1. Uswah Hasanah (Leadership)

Nilai uswah hasanah digunakan untuk mendorong adanya prilaku yang mengarah pada integritas, profesional, kreatif, inovatif dan produktif dalam diri setiap sivitas akademik Fakultas Ushuluddin dalam menciptakan budaya akademik yang berpegang teguh pada nilai-nilai keislaman dan keindonesiaan sehingga menjadi role model kemajuan dan kemanfaatan di masa yang akan datang (Penyusun, 2019a).

2. Khidmah (Service Excellence)

Nilai khidmah dikembangkan dalam upaya menumbuhkan komitmen pelayanan prima dan peningkatan kualitas yang berkelanjutan dalam seluruh proses akademik. Dalam hal ini, perilaku sivitas akademik Fakultas Ushuluddin diarahkan untuk saling mendukung satu sama lain, menghargai proses, fokus terhadap tujuan, dinamis, antisipatif, dan solutif (Penyusun, 2019a).

3. Wasathiyah (Moderation)

Nilai wasathiyah dikembangkan dalam upaya menghidupkan keseimbangan, keteraturan dan harmoni dalam proses pengelolaan lembaga melalui kolaborasi, partisipasi, transparansi dan demi kepentingan terbaik bagi lembaga sehingga seluruh sivitas akademik Fakultas Ushuluddin merasa menjadi bagian penting dalam proses kemajuan dan peningkatan kualitas hidup masyarakat, negara dan bangsa (Penyusun, 2019a).

Ketiga nilai-nilai inti di atas, yakni uswah hasanah, khidmah, dan wasathiyah, tentunya sangat berkaitan erat dengan pribadi Nabi Saw. (Darmawan et al., 2006). Diyakni pribadi Nabi Saw. merupakan ahlak AlQur'an (Syuhud, 2010). Allah Swt sendiri dalam Al-Qur'an berfirman bahwa al-Qur'an merupakan kalam Allah Swt. (Rusydi, 2017). Parktis, pada diri Nabi Saw. tidak ada kesalahan sebagai pribadi yang maksum (Fuadi, 2018). Tidak diragukan, Nabi Saw adalah uswah hasanah dalam segala aspek 
Jurnal Riset Agama, Volume 1, Nomor 3 (Desember 2021): 157-170

Siti Rahmah, Wahyudin Darmalaksana, Susanti Vera, Muhamad Yoga Firdaus, Hidayatul Fikra/Nilai-nilai Inti Sistem Manajemen Strategis pada Pengelolaan Pendidikan Tinggi: Studi Living Hadis

kehidupan (Alwi, 2009). Daripada itu, Rasulullah Saw. sangat mengutamakan pelayanan (khidmah) terhadap kepentingan umat (Ulum, 2014). Bahkan, moderasi (wasathiyah) beragama (Sutrisno, 2019) juga dapat ditelusuri seluk-beluknya sebagai ajaran dari Nabi Saw. (Zulkifli, 2018). Nilai uswatun hasanah, khidmah, dan wasathiyah, dipahami sebagai bagian dari nilai-nilai inti Islam (Samsuni, 2020) yang dimanifestasikan dari Nabi Saw. (Darmawan et al., 2006) serta merupakan nilai yang hidup (living), dirawat, dan dilaksanakan (Qudsy, 2016) di Indonesia sebagai negara dengan mayoritas penduduk muslim (Arsyita, 2020).

Nilai uswah hasanah berkorelasi dengan bidang kepemimpinan (leadership). Fakultas Ushuluddin menggunakan nilai uswah hasanah dengan maksud untuk mendorong adanya prilaku yang mengarah pada integritas, profesional, kreatif, inovatif dan produktif (Penyusun, 2019a). Hal ini di dalam manajemen modern diakui merupakan karakteristik primer suatu kepemimpinan (Focht \& Ponton, 2015). Nilai uswah hasanah merupakan karakter yang melekat dalam aspek kepemimpinan dan manajerial yang diteladankan Nabi Saw. (Umam, 2018). Ditegaskan dalam rencana strategis bahwa, berbasis pada pemikiran uswah hasanah (Rachmawati, 2017), Fakultas Ushuluddin bermaksud menciptakan budaya akademik yang berpegang teguh pada nilai-nilai keislaman dan keindonesiaan (Penyusun, 2019a). Fakultas Ushuluddin mendasarkan bahwa hebatnya ketauladanan Rasulullah Saw. (Zabidi, 2013), diharapkan menjadi role model kemajuan dan kemanfaatan (kemaslahatan) strategis (Firdaus, 2018) di masa mendatang (Penyusun, 2019a).

Nilai khidmah dikembangkan fakultas ini dalam upaya menumbuhkan komitmen pelayanan prima dan peningkatan kualitas yang berkelanjutan dalam seluruh proses akademik (Penyusun, 2019a). Diakui aspek pelayanan prima dan peningkatan kualitas merupakan subjek yang selaras dengan semangat Islam (Samsuni, 2020) berkenaan dengan etos kerja (Kirom, 2018). Hal ini pun merupakan suatu subjek yang sangat ditekankan dari perspektif kandungan al-Qur'an (Juliena, 2015), (Taufiq, 2004). Sejalan dengan ini, perilaku sivitas akademik fakultas diarahkan untuk saling mendukung satu sama lain, menghargai proses, fokus terhadap tujuan, dinamis, antisipatif, dan solutif (Penyusun, 2019a). Tegaslah bahwa nilai khidmat yang dikembangkan Fakultas Ushuluddin untuk mencapai sasaran strategis dipahami sebagai basis ajaran Nabi Saw yang berdimensi ilahiyah (Darmawan et al., 2006) sebagai pribadi yang menekankan keutamaan pelayanan (Ulum, 2014), tentu dengan tanpa adanya diskriminasi gender antara laki-laki dan perempuan (Nazim et al., 2012).

Fakultas ini mengembangkan nilai wasathiyah sebagai mandate rencana strategis kementerian (Penyusun, 2020) dan universitas (Penyusun, 2019b). Hal ini dikembangkan dalam upaya menghidupkan keseimbangan, keteraturan dan harmoni (Kawangung, 2019) dalam proses manajemen 
Jurnal Riset Agama, Volume 1, Nomor 3 (Desember 2021): 157-170

Siti Rahmah, Wahyudin Darmalaksana, Susanti Vera, Muhamad Yoga Firdaus, Hidayatul Fikra/Nilai-nilai Inti Sistem Manajemen Strategis pada Pengelolaan Pendidikan Tinggi: Studi Living Hadis

strategis fakultas (Penyusun, 2019a). Subjek pengarusutamaan wasathiyah (Shihab, 2019) diyakini merupakan hasil penggalian dari kandungan dari al-Qur'an (Ikhsan, 2019). Secara aksiologis, nilai wasathiyah (Ikhsan, 2019) diterapkan melalui kolaborasi, partisipasi, dan transparansi demi kepentingan terbaik bagi lembaga (Penyusun, 2019a). Tidak dipungkiri bahwa kolaborasi (Viale Pereira et al., 2017), partisipasi, dan transparansi serta inovasi dipahami sebagai tantangan manajemen strategis modern (Reggi \& Dawes, 2016). Melalui nilai wasathiyah (Fauzi, 2018) diarahkan agar seluruh sivitas merasa menjadi bagian penting dalam proses kemajuan dan peningkatan kualitas hidup masyarakat, negara dan bangsa (Penyusun, 2019a). Hal ini menegaskan bahwa sikap moderasi (Karim, 2019) merupakan aksiologi nilai inti Islam dari pemahaman hadis Nabi Saw. (Zulkifli, 2018).

Paparan di atas menegaskan tiga hal utama. Pertama, nilai uswah hasanah dari Nabi Saw. (Darmawan et al., 2006) merupakan ajaran sempurna dalam pengendalian lembaga berbasis nilai (Eferin, 2016). Nilai ini diterapkan dalam sistem manajemen strategis (Hakim, 2020) Fakultas Ushuluddin dalam rangka pencapaian sasaran strategis tujuan bersama (Oja, 2016). Sekecil apapun pencapaian tanpa melihat materialnya (Eferin, 2016) merupakan bentuk uswah hasanah yang sepatutnya mendapat apresiasi (Samsuni, 2020). Kedua, pelaksanaan nilai khidmat pada manajemen strategis lembaga (Sedjati, 2015) dengan core business pendidikan (Nagy, 2011) berorientasi untuk peningkatan pelayanan dari pelayanan standar ke pelayanan prima (Wisdaningrum, 2013). Ketiga, nilai moderasi (Islam, 2020) secara aksiologis dan praktis dilaksanakan melalui kolaborasi yang menjadi tantangan manajemen strategis modern (Viale Pereira et al., 2017). Ketiga nilai inti ini menurut analisis living hadis (Darmalaksana et al., 2019) dipahami sebagai rujukan perilaku keorganisasian (Kurniawan, 2016) terlebih lagi sebagai pembentuk decision maker kemajuan kelembagaan berbasis pencapaian sasaran strategis (Fattah, 2015).

\section{Kesimpulan}

Metode living hadis relevan digunakan untuk penelitian nilai-nilai inti dalam sistem manajemen strategis sebagai inisiatif lembaga dalam upaya mereka melakukan pencapaian sasaran strategis. Penelitian ini diharapkan berimplikasi manfaat untuk perencanaan startegis kalangan manager lembaga dalam pencapaian sasaran strategis berbasis nilai-nilai inti. Penelitian ini terdapat keterbatasan (limitation), yakni hanya membuka pintu studi living hadis ke bidang pengetahuan strategic management, sehingga dibutuhkan penelitian lebih mendalam dengan mengakomodasi pendekatan syarah teks hadis. Penelitian ini merekomendasikan pentingnya pengembangan studi hadis di satu sisi, dan 
Jurnal Riset Agama, Volume 1, Nomor 3 (Desember 2021): 157-170

Siti Rahmah, Wahyudin Darmalaksana, Susanti Vera, Muhamad Yoga Firdaus, Hidayatul Fikra/Nilai-nilai Inti Sistem Manajemen Strategis pada Pengelolaan Pendidikan Tinggi: Studi Living Hadis

pengembangan lembaga berbasis nilai-nilai inti sebagai rujukan pengambilan keputusan di sisi lain. 
Jurnal Riset Agama, Volume 1, Nomor 3 (Desember 2021): 157-170

Siti Rahmah, Wahyudin Darmalaksana, Susanti Vera, Muhamad Yoga Firdaus, Hidayatul Fikra/Nilai-nilai Inti Sistem Manajemen Strategis pada Pengelolaan Pendidikan Tinggi: Studi Living Hadis

\section{Daftar Pustaka}

Adhim, F., \& Hakim, M. N. (2019). Perencanaan Strategi Berbasis Nilai di Lembaga Pendidikan Tinggi. Nidhomul Haq: Jurnal Manajemen Pendidikan Islam, 4(2), 259-279.

Alwi, H. (2009). Uswatun Hasanah. Hikmah.

Anggito, A., \& Setiawan, J. (2018). Metodologi penelitian kualitatif. CV Jejak (Jejak Publisher).

Ansoff, H. I., Kipley, D., Lewis, A. O., Helm-Stevens, R., \& Ansoff, R. (2018). Implanting strategic management. Springer.

Anwar, M. K. (2015). living Hadis. Farabi: Journal of Ushuluddin E Islamic Thought, 12(1), 72-86.

Arsyita, A. (2020). Peran Islam Dalam Pembangunan Bangsa Indonesia. JURNAL NAGUR, 1(1), 9-20.

Assagaf, J. (2015). Studi Hadis Dengan Pendekatan Sosiologis: Paradigma Living-Hadis. Holistic Al-Hadis, 1(2), 289-316.

Brata, I. B. (2016). Kearifan budaya lokal perekat identitas bangsa. Jurnal Bakti Saraswati (JBS), 5(1).

Breuer, H., \& Lüdeke-Freund, F. (2017). Values-based network and business model innovation. International Journal of Innovation Management, 21(03), 1750028.

Darmalaksana, W. (2020a). Formula Penelitian Pengalaman Kelas Menulis. Jurnal Kelas Menulis UIN Sunan Gunung Djati Bandung. http://digilib.uinsgd.ac.id/32620/

Darmalaksana, W. (2020b). Metode Penelitian Kualitatif Studi Pustaka dan Studi Lapangan. Pre-Print Digital Library UIN Sunan Gunung Djati Bandung.

Darmalaksana, W., Alawiah, N., Thoyib, E. H., Sadi'ah, S., \& Ismail, E. (2019). Analisis Perkembangan Penelitian Living Al-Qur'an dan Hadis. Jurnal Perspektif, 3(2), 134-144.

Darmalaksana, W., Pahala, L., \& Soetari, E. (2017). Kontroversi Hadis sebagai Sumber Hukum Islam. Wawasan: Jurnal Ilmiah Agama Dan Sosial Budaya, 2(2), 245-258.

Darmawan, C., Suryani, Y., \& Handayani, D. (2006). Kiat Sukses Manajemen Rasulullah: manajemen sumber daya insani berbasis nilai-nilai ilahiyah. Khazanah Intelektual.

Dewi, S. K. (2017). Fungsi Performatif dan Informatif Living Hadis dalam Perspektif Sosiologi Reflektif. Jurnal Living Hadis, 2(2), 179-207.

Eferin, S. (2016). Sistem Pengendalian Manajemen Berbasis Spiritualitas. Yayasan Rumah Peneleh.

Fattah, N. (2015). Manajemen Stratejik Berbasis Nilai. Bandung: Rosda.

Fauzi, A. (2018). Moderasi Islam, Untuk Peradaban Dan Kemanusiaan. Jurnal Islam Nusantara, 2(2), 232-244.

Firdaus, A. (2018). Mengembangkan Siklus Penerapan Sistem Manajemen 
Jurnal Riset Agama, Volume 1, Nomor 3 (Desember 2021): 157-170

Siti Rahmah, Wahyudin Darmalaksana, Susanti Vera, Muhamad Yoga Firdaus, Hidayatul Fikra/Nilai-nilai Inti Sistem Manajemen Strategis pada Pengelolaan Pendidikan Tinggi: Studi Living Hadis

Kinerja Berbasis Kemaslahatan. Al-Uqud: Journal of Islamic Economics, 2(1), 94-120.

Focht, A., \& Ponton, M. (2015). Identifying primary characteristics of servant leadership: Delphi study. International Journal of Leadership Studies, 9(1).

Fuadi, A. R. (2018). Pandangan Mufasir Tentang Sifat Kemaksuman Nabi Muhammad Saw. UIN Ar-Raniry Banda Aceh.

Hakim, L. (2020). Implementasi Manajemen Berbasis Nilai Pada Organisasi Pendidikan. Al Ta'dib: Jurnal Ilmu Pendidikan, 9(2), 78-98.

Hudaeri, M. (2016). Pendekatan Kuantitatif, Kualitatif Dan Kritis Sebagai Alat Bantu Dalam Kajian Living Hadis. Holistic Al-Hadis, 2(1), 25-46.

Ikhsan, M. A. (2019). Al-Quran Dan Deradikalisasi Paham Keagamaan Di Perguruan Tinggi: Pengarusutamaan Islam Wasathiyah. Al-Bayan: Jurnal Ilmu Al-Qur'an Dan Hadist, 2(2), 98-112.

Islam, K. N. (2020). Moderasi Beragama di Tengah Pluralitas Bangsa: Tinjauan Revolusi Mental Perspektif Al-Qur'an. KURIOSITAS: Media Komunikasi Sosial Dan Keagamaan, 13(1).

Juliena, D. (2015). Etos kerja dalam perspektif al-Qur'an (studi analisis). UIN Walisongo.

Karim, H. A. (2019). Implementasi Moderasi Pendidikan Islam Rahmatallil' Alamin dengan Nilai-Nilai Islam. Ri'ayah: Jurnal Sosial Dan Keagamaan, 4(01), 1-20.

Kawangung, Y. (2019). Religious moderation discourse in plurality of social harmony in Indonesia. International Journal of Social Sciences and Humanities, 3(1), 160-170.

Kirom, C. (2018). Etos Kerja Dalam Islam. Tawazun: Journal Of Sharia Economic Law, 1(1), 57-72.

Klass, M. (2018). Ordered universes: Approaches to the anthropology of religion. Routledge.

Kurniawan, A. (2016). Implementasi Manajemen Berbasis Nilai Pada Organisasi. Menara Tebuireng, 11(02), 159-176.

Lutz, D. J., Boon, A. T., \& Xue, X. (2016). Resolving Ethical Dilemmas in Academic Advising through Core Values and Aspirational Principles. Mentor: An Academic Advising Journal.

Masrur, A. (2012). Diskursus Metodologi Studi Hadis Kontemporer Analisa Komparatif antara Pendekatan Tradisional dan Pendekatan Revisionis. Journal of Qur'an and Hadith Studies, 1(2), 237-249.

Mook, L. (2019). The Sustainable Development Goals: A Tipping Point for Impact Measurement? Canadian Journal of Nonprofit and Social Economy Research, 10(2).

Muhammad, M. (2018). Living Hadis: Sebuah Kajian Epistemologis. FIKROH: Jurnal Pemikiran Dan Pendidikan Islam, 11(1), 12-33.

Muhsin, M. (2015). Memahami Hadis Nabi dalam Konteks Kekinian: Studi 
Jurnal Riset Agama, Volume 1, Nomor 3 (Desember 2021): 157-170

Siti Rahmah, Wahyudin Darmalaksana, Susanti Vera, Muhamad Yoga Firdaus, Hidayatul Fikra/Nilai-nilai Inti Sistem Manajemen Strategis pada Pengelolaan Pendidikan Tinggi: Studi Living Hadis

Living-Hadis. Holistic Al-Hadis, 1(1), 1-24.

Nagy, J. (2011). Scholarship in higher education: Building research capabilities through core business. British Journal of Educational Studies, 59(3), 303-321.

Nazim, A. M., Sham, F. M., \& Hamjah, S. H. (2012). Khidmat Sosial Wanita pada Zaman Rasulullah SAW. Al-Hikmah, 4, 37-49.

Noor, K. B. M. (2008). Case study: A strategic research methodology. American Journal of Applied Sciences, 5(11), 1602-1604.

Oja, H. (2016). Penerapan Manajemen Strategi Dalam Mewujudkan Kinerja Organisasi Sektor Publik. Societas: Jurnal Ilmu Administrasi Dan Sosial, $5(1), 1-11$.

Pedron, C. D., Picoto, W. N., Dhillon, G., \& Caldeira, M. (2016). Valuefocused objectives for CRM system adoption. Industrial Management $\mathcal{E}$ Data Systems.

Penyusun, T. (2019a). Rencana Strategis Fakultas Ushuluddin UIN Sunan Gunung Djati Bandung Periode 2019 - 2023. Fakultas Ushuluddin UIN Sunan Gunung Djati Bandung.

Penyusun, T. (2019b). Rencana Strategis UIN Sunan Gunung Djati Bandung 2019-2023. UIN Sunan Gunung Djati Bandung.

Penyusun, T. (2020). Rencana Strategis Kementerian Agama 2020-2024. Kementerian Agama Republik Indonesia.

Peterson, M. F., \& Barreto, T. S. (2018). Interpreting societal culture value dimensions. Journal of International Business Studies, 49(9), 1190-1207.

Putra, A., Yasir, M., \& Riau, U. I. N. S. S. Q. (2018). Kajian Al-Qur'an Di Indonesia: Dari Studi Teks Ke Living Qur'an. Majalah Ilmu Pengetahuan Dan Pemikiran Keagamaan Tajdid, 21(2), 13-22.

Qudsy, S. Z. (2016). Living Hadis: Genealogi, Teori, dan Aplikasi. Jurnal Living Hadis, 1(1), 177-196.

Rachmawati, F. (2017). RETHINKING USWAH HASANAH: Etika Dakwah dalam Bingkai Hiperrealitas. Jurnal Ilmu Dakwah, 35(2), 307-329.

Reggi, L., \& Dawes, S. (2016). Open government data ecosystems: Linking transparency for innovation with transparency for participation and accountability. International Conference on Electronic Government, 74-86.

Rohmana, J. A. (2015). Pendekatan Antropologi Dalam Studi Living Hadis Di Indonesia: Sebuah Kajian Awal. Holistic Al-Hadis, 1(2), 247-288.

Rusydi, A. M. (2017). Aktualisasi Nilai-nilai al-Qur'an di Era Modern. Jurnal Ulunnuha, 6(2), 109-119.

Salleh, N. M., Shamsu, L. S. H., Wazir, R., Usman, A. H., Abdullah, M. F. R., Ismail, A. Z., \& Burhanuddin, N. A. (2019). Penyalahgunaan Living Hadis dalam Kalangan Kelompok Liberal: Satu Sorotan Literatur Secara Sistematik. HADIS, 9(17), 65-78.

Salleh, N. M., Usman, A. H., Wazir, R., Shamsu, L. S. H., \& Burhanuddin, N. A. (2020). Living Sunnah Menurut Fazlur Rahman: Satu Sorotan 
Jurnal Riset Agama, Volume 1, Nomor 3 (Desember 2021): 157-170

Siti Rahmah, Wahyudin Darmalaksana, Susanti Vera, Muhamad Yoga Firdaus, Hidayatul Fikra/Nilai-nilai Inti Sistem Manajemen Strategis pada Pengelolaan Pendidikan Tinggi: Studi Living Hadis

Literatur Secara Sistematik. AL-BURHĀN: JOURNAL OF QUR'ĀN AND SUNNAH STUDIES, 4(1), 127-141.

Samsuni, S. (2020). Manajemen Sumber Daya Manusia Berbasis Nilai-Nilai Islami. Tarbiyah Islamiyah: Jurnal Ilmiah Pendidikan Agama Islam, 10(1).

Schwartz, M. S. (2016). Ethical decision-making theory: An integrated approach. Journal of Business Ethics, 139(4), 755-776.

Sedjati, R. S. (2015). Manajemen Strategis. Deepublish.

Shihab, M. Q. (2019). Wasatiyah Wawasan Islam tentang Moderasi Beragama. Tangerang: Lentera Hati.

Soetari, E. (1994). Ilmu Hadits. Amal Bakti Press.

Suharto, T. (2018). Pemetaan Ayat-Ayat al-Qur'an tentang Rumpun Ilmu Agama dalam Perspektif Paradigma Integrasi-Interkoneksi. Intizar, 24(1), 83-102.

Sulastri, L. (2013). Kajian Manajemen Berbasis Nilai Dalam Konteks Perguruan Tinggi (Studi Kasus pada Perguruan Tinggi Binus University). UNPAS.

Suryadilaga, M. A. (2005). Model-Model Living Hadis. Metodologi Penelitian Living Qur'an Dan Hadith, Edited by Sahiron Syamsuddin (Nd), 107-114.

Suryadilaga, M. A. (2006). Living Hadis dalam Kerangka Dasar Keilmuan UIN Sunan Kalijaga. Yogyakarta: DIPA UIN Sunan Kalijaga.

Suryadilaga, M. A. (2007). Implementasi Pendekatan Integrasi-Interkoneksi dalam Kajian Living Hadis. Islamic Studies dalam Paradigma IntegrasiInterkoneksi: Sebuah Antologi ....

Sutomo, S. (2007). Manajemen Strategis Organisasi Nirlaba. Kesmas: National Public Health Journal, 1(4), 176-187.

Sutrisno, E. (2019). Aktualisasi Moderasi Beragama di Lembaga Pendidikan. Jurnal Bimas Islam, 12(2), 323-348.

Syamsuddin, S. (2007). Metodologi Penelitian Living Qur'an dan Hadis. Yogyakarta: Teras.

Syuhud, A. F. (2010). Pribadi Akhlakul Karimah. A. Fatih Syuhud.

Taufiq, A. M. (2004). Praktik manajemen berbasis Al-Qur'an. Gema Insani.

Tim Penyusun. (2019). Keputusan Direktur Jenderal Pendidikan Islam Nomor 2498 Tahun 2019 tentang Pedoman Implementasi Integrasi Ilmu di PTKI.

Ulum, M. (2014). Hadis-Hadis Tentang Etos Kerja (Telaah Ma" anil Hadis).

Umam, M. K. (2018). Imam Para Nabi: Menelusur Jejak Kepemimpinan dan Manajerial Nabi Muhammad saw. Al-Hikmah: Jurnal Kependidikan Dan Syariah, 6(1), 59-74.

Viale Pereira, G., Cunha, M. A., Lampoltshammer, T. J., Parycek, P., \& Testa, M. G. (2017). Increasing collaboration and participation in smart city governance: a cross-case analysis of smart city initiatives. Information Technology for Development, 23(3), 526-553.

Wahab, M. A. (2017). Relationships between religious work values, sustainable work behaviours and sustainable energy consumptions. Management Decision. 
Jurnal Riset Agama, Volume 1, Nomor 3 (Desember 2021): 157-170

Siti Rahmah, Wahyudin Darmalaksana, Susanti Vera, Muhamad Yoga Firdaus, Hidayatul Fikra/Nilai-nilai Inti Sistem Manajemen Strategis pada Pengelolaan Pendidikan Tinggi: Studi Living Hadis

Wisdaningrum, O. (2013). Analisis rantai nilai (value chain) dalam Lingkungan internal perusahaan. Jurnal ANALISA, 1(1).

Yu, E., \& Sangiorgi, D. (2018). Service design as an approach to implement the value cocreation perspective in new service development. Journal of Service Research, 21(1), 40-58.

Yunus, E. (2016). Manajemen Strategis. Penerbit Andi.

Zabidi, A. Z. M. (2013). Hebatnya Rasulullah. Karya Bestari.

Zainiyati, H. S. (2015). Landasan Fondasional Integrasi Keilmuan di UIN Maulana Malik Ibrahim Malang dan UIN Sunan Ampel Surabaya. Islamica: Jurnal Studi Keislaman, 10(01), 248-276.

Zhang, L., \& El-Gohary, N. M. (2016). Discovering stakeholder values for axiology-based value analysis of building projects. Journal of Construction Engineering and Management, 142(4), 4015095.

Zuhri, S., \& Dewi, S. K. (2018). Living Hadis; Praktik, Resepsi, Teks, dan Transmisi. Yogyakarta: Q-Media.

Zulkifli, R. (2018). Moderasi Pemahaman Hadis dalam Hukum Islam Menurut Al-Qaradhawi. El-Buhuth: Borneo Journal of Islamic Studies, 1(1). 